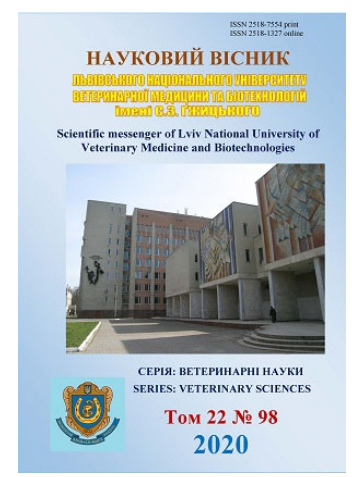

Науковий вісник Дьвівського національного університету ветеринарної медицини та біотехнологій імені С.3. Гжицького. Серія: Ветеринарні науки

\author{
Scientific Messenger of Lviv National University \\ of Veterinary Medicine and Biotechnologies. \\ Series: Veterinary sciences
}

doi: $10.32718 /$ nvlvet9819

https://nvlvet.com.ua/index.php/journal

UDC 636.09:664.696:636.085:637.5:577.213

\title{
Metods of adulteration detection of meat products (review article)
}

\author{
I. Oleksiienko ${ }^{1}$, O. Haidei ${ }^{1}$, G. Kyivska ${ }^{1}$, O. Krushelnytska ${ }^{2}$ \\ ${ }^{1}$ State Scientific and Research Institute of Laboratory Diagnostics and Veterinary and Sanitary Expertise, Kyiv, Ukraine \\ ${ }^{2}$ Stepan Gzhytskyi National University of Veterinary Medicine and Biotechnologies Lviv, Ukraine
}

Article info

Received 13.04.2020

Received in revised form 18.05.2020

Accepted 19.05.2020

State Scientific and Research Institute of Laboratory Diagnostics And Veterinary and Sanitary Expertise, Donetska Str., 30 Kyiv, 03151, Ukraine. Tel.: +38-098-782-55-24 E-mail: ira.oleksiienko@gmail.com

Stepan Gzhytskyi National University of Veterinary Medicine and Biotechnologies, Pekarska Str., 50, Lviv, 79010, Ukraine. Tel.: +38-067-713-07-28 E-mail: olena.krushelnytska@gmail.com
Oleksiienko, I., Haidei, O., Kyivska, G., \& Krushelnytska, O. (2020). Metods of adulteration detection of meat products (review article). Scientific Messenger of Lviv National University of Veterinary Medicine and Biotechnologies. Series: Veterinary sciences, 22(98), $108-112$. doi: $10.32718 /$ nvlvet 9819

Today a topical issue is the adulteration of meat products in Ukraine and in the world. In this regard, to exchange information and combat cases of fraud, world networks, platforms, databases, special units, target groups and the like were created. According to the Consumer Rights Protection Committee, about $80 \%$ of food products in Ukraine are falsified, about $60 \%$ are meat products. For example, mechanically deboned meat, meat and bone meal, emulsions, soya protein, etc. not used for animal feed, but for the replacement (reduction) of raw meat in the manufacture of meat products. The entrepreneur has the opportunity to independently develop and be guided by the technical specifications, which enables him to falsify the products. Consumers buying such products, experiencing economic and moral damage. The aim of the work was to review existing methods for detecting falsification of meat products and select the most optimal. The following methods are used to determine of adulteration: microstructural histological analysis, enzyme-linked immunosorbent assay (ELISA), polymerase chain reaction (PCR). Research showed that the histological method can determine the origin, type of components and doesn't detect the species; immunological suitable for study of raw meat and raw materials. The most accurate and informative is the PCR method, which, due to its high sensitivity, allows you to establish the species of meat products and the quantitative content of raw meat. The PCR method has its drawbacks: the risk of contamination and exposure to inhibitors. Therefore, it is important to choose the best purification method and DNA extraction. An important aspect when conducting PCR studies is the mandatory observance of all the requirements of the study, in particular measures to prevent contamination to obtain the correct result. The prospect of further research is the improvement of existing methods for the study of meat products and the implementation of monitoring research.

Key words: meat products, meat raw material, adulteration, laboratory diagnostic, immunological methods, molecular genetically methods, PCR, species distinctive.

\section{Методи визначення фальсифікації м'ясних продуктів (оглядова стаття)}

\author{
I. С. Олексієнко ${ }^{1}$, О. С. Гайдей ${ }^{1}$, Г. В. Київська ${ }^{1}$, О. В. Крушельницька ${ }^{2}$ \\ ${ }^{1}$ Державний науково-дослідний інститут з лабораторної діагностики та ветеринарно-санітарної експерти- \\ зи, м. Київ, Украӥна \\ ${ }^{2}$ Львівський національний університет ветеринарної медицини та біотехнологій імені С. 3. Гюиџького, м. Львів, \\ Україна
}

Актуальним питанням на сьогодні в Украӥні та Світі є фальсифікаџія м'ясних продуктів. У зв 'язку з цим, для обміну інформацією та боротьби з випадками фальсифікації було створено світові мережі, платформи, бази даних, спеціальні підрозділи, иільові групи тощо. За даними Комітету охорони прав споживачів, близько 80 \% харчових продуктів в Украӥні фальсифіковано, з них близько 60 \% - ие м'ясні продукти. Наприклад, мясо механічної обвалки (ММО), м'ясо-кісткове борошно, емульсії, соєвий білок тощо використовують не для корму тваринам, а для заміни (здешевлення) м'ясної сировини при виготовленні м'ясних продуктів. 
Підприємецьь має змогу самостійно розробляти та керуватись ТУ, щчо дає можливість йому фальсифікувати продукцію. Споживачі, купуючи таку продукиію, зазнають економічних та моральних збитків. Метою роботи було провести огляд існуючих методів виявлення фальсифікації м'ясних продуктів та обрати найбільш оптимальні. Для визначення фальсифікації використовують наступні методи: мікроструктурний гістологічний аналіз, імуноферментний аналіз (ЕLISA), полімеразно-ланиюгову реакцію (ПЛР). Огляд показав, шчо гістологічним методом можна встановити походження, вид компонентів та не можливо встановити видову приналежність; імунологічний підходить для дослідження сирої м'ясної сировини. Найбільш точним та інформативним є метод ПЛР, який завдяки високій чутливості дозволяє встановити видову приналежність м'ясних продуктів та кількісний вміст м'ясної сировини. Метод ПЛР має свої недоліки: ризик контамінації та впливу інгібіторів. Тому важливо обрати оптимальний метод очистки та ДНК екстракиї. Важливим аспектом при проведенні досліджень методом ПЛР є обов'язкове дотримання всіх вимог проведення дослідження, зокрема, заходів запобігання контамінаиї для отримання коректного результату. Перспективою подальших досліджень є вдосконалення існуючих методів дослідження м'ясних продуктів та впровадження моніторингових досліджень.

Ключові слова: м'ясні продукти, м'ясна сировина, фальсифікація, лабораторна діагностика, імунологічні методи, молекулярно-генетичні методи, ПЛР, видова приналежність.

\section{Ветуп}

В останні роки фальсифікація продовольчих товарів $\epsilon$ центром уваги громадськості, що стало причиною створення національних, регіональних, міжнародних мереж і платформ по боротьбі з фальсифікацією продуктів харчування та обміну інформацією (наприклад, Європол, база даних США, Фармакопейна конвенція (USP), мережа продовольчої фальсифікації ЕC, спеціальні підрозділи або спеціальні цільові групи деяких країн для боротьби з фальсифікацією продуктів харчування (FSA Ірландія, FSA, USFDA)). Відсутні офіційні програми контролю продуктів харчування по боротьбі з кримінальними аспектами фальсифікації харчових продуктів. Навколо даного питання виникають світові скандали (наприклад, з кониною у СС), втрата довіри споживачів та серйозні економічні наслідки (P'ervinchenci, 2016; The EU Food Fraud Network; Informatsiina systema Yevropol).

За даними Комітету охорони прав споживачів, в Україні близько 80 \% харчових продуктів фальсифіковано за одним або декількома показниками, близько 60 \% з яких становлять м'ясні продукти (Sidnieva \& Rybachuk-Yarova, 2015).

Більшість виробників використовують у своїй продукції малоцінну сировину, не зазначаючи іiі на упаковці, розробляють власні ТУ, що дає можливість змінювати рецептуру для здешевлення товару.

Найчастіше м'ясні продукти фальсифікують шляхом заміни одного виду сировини іншим, дешевим i малоцінним: ММО, субпродукти, м'ясо-кісткове борошно, сухожилки тощо. Вдаються до видової фальсифікації, наприклад яловичину замінюють кониною, свининою та курятиною. Також додають сухе молоко, яєчний порошок та рослинну сировину (соєвий білок, борошно, крохмаль, рослинні жири), емульгатори, стабілізатори, барвники, ароматизатори, воду, вологоутримуючі компоненти, антибактеріальні препарати, підсилювачі смаку, хімічні сполуки та інші харчові добавки (Humeniuk, 2009; Krysanov, 2010; Fomina \& Minaev, 2011; Khimich et al., 2020).

У ст. 11 Закону України № 2639-VIII від 06.12.2018 “Про інформацію для споживачів щодо харчових продуктів" зазначено, що виробник несе відповідальність за інформацію, вказану на етикетці харчового продукту. Вона повинна надаватися у повному обсязі, бути легкодоступною для споживачів. У маркуванні харчових продуктів має зазначатись інформація про заміну інгредіснтів або компонентів, наявність доданої води (якщо додавання становить більше 5 \% маси готового продукту), наявність білків, включно з гідролізованими різного тваринного походження, назва інгредієнтів, харчових добавок та харчових ензимів, поєднання яких може справляти враження цілого шматка м'яса (Zakon Ukrainy, 2018).

Як правило, виробники на етикетці зазначають не всю інформацію або зазначають іï частково. Товар нижчого сорту замасковується під продукцію високої якості шляхом приховування від споживача складу та співвідношення компонентів та реалізується за високою вартістю. Крім того, фальсифікація видового складу м'ясної сировини у багатокомпонентних м'ясних продуктах може нанести моральну шкоду категорії споживачів, національні або релігійні погляди яких не дозволяють вживання певних видів м'яса (наприклад, халяльні та кошерні продукти) (Krysanov, 2010; Shchebentovska \& Kotsiumbas, 2012).

Мета $і$ завдання. Огляд існуючих методів фальсифікації м'ясних продуктів та встановлення видової приналежності $з$ метою вибору оптимального напряму подальших досліджень.

\section{Матеріал і методи досліджень}

Українські та закордонні літературні джерела щодо визначення фальсифікації м'ясних продуктів.

\section{Результати та їх обговорення}

Для визначення видової приналежності використовують наступні методи: мікроструктурний гістологічний аналіз, імунологічний - імуноферментний аналіз (ELISA), молекулярно-генетичний - полімеразно-ланцюгова реакція (ПЛР).

Принцип мікроструктурного гістологічного аналізу грунтується на вивченні особливостей мікроструктури та хімічних властивостей компонентів.

На основі морфологічних особливостей структур можна встановити походження наявних компонентів, зокрема рослинних включень, таких як: соєвий ізольований білок і крохмаль, визначити склад продукту, ідентифікувати різноманітні спеції, харчові добавки, гелеутворювачі тощо (Kotsiumbas et al., 2011; Shutchenko et al., 2013; Lozhkina et al., 2013). 
Недоліками мікроструктурного методу є: довготривалість, складність проведення досліджень та недостатня об'єктивність результатів. Даним методом не можливо встановити видову приналежність тваринних інгредієнтів (Vlizlo et al., 2012; Waiblinger et al., 2017).

Імуноферментний аналіз (ELISA) - метод виявлення тваринних білків у сирій м'ясній сировині. Межа виявлення становить від $1 \%$ до $5 \%$. Чутливість методу залежить від виду м'ясної сировини чи використаного м'ясного компоненту (м'язова тканина або лівер) та ступеня термічної обробки (Kotsiumbas \& Shchebentovska, 2011; Waiblinger et al., 2017).

Імунологічні методи контролю не достатньо ефективні для ідентифікації подрібненої м'ясної сировини в готових продуктах, особливо якщо кількість м'ясної фальсифікуючої суміші не значна у співвідношенні до основної сировини. Крім того, ці методи практично не придатні для дослідження м'ясних сумішей отриманих 3 м'яса споріднених видів тварин, а також для виявлення фальсифікації м'ясних продуктів, що пройшли термічну обробку (Komarova, 2005; Waiblinger et al., 2017).

Полімеразно-ланцңюгова реакція - сучасний молекулярно-генетичний метод, який широко використовується у лабораторній практиці. Принцип методу грунтується на виявленні у матеріалі специфічних фрагментів ДНК різноманітних об'єктів, їхньому вибірковому синтезі до концентрації, за якої їх легко детектувати, i подальшій інтерпретації продуктів реакції - ампліконів (Schrader et al., 2012; Ishchenko et al., 2016; PCR Amplification).

На відміну від білків, ДНК більш стійка до термічної обробки, тому перспективним методом для ідентифікації видового складу м'ясних компонентів є полімеразна ланцюгова реакція у різних іiі модифікаціях (Liubchyk et al., 2014; Waiblinger et al., 2017).

Використання методу ПЛР передбачає наявність висококваліфікованого персоналу, облаштованої згідно вимог лабораторії з окремими зонами для кожного етапу проведення дослідження, суворо стаціонарного обладнання 3 метою запобігання контамінації (Nakaz Ministerstva, 2008).

Головним недоліком ПЛР є чутливість до інгібіторів, які пригнічують реакцію. М'ясний продукт складна матриця, яка містить у своєму складі, крім м'язової тканини та субпродуктів, інгібуючі речовини (жири, спеції, емульгатори, консерванти, барвники тощо), які є причиною зменшення чутливості реакції та отримання хибно-негативного або неспецифічного результату.

У зв'язку з цим, для отримання коректного результату дуже важливо обрати оптимальний метод очищення зразка від інгібіторів та спосіб екстракції нуклеїнових кислот.

ПЛР включає наступні етапи: пробопідготовка зразка, ДНК екстракція, приготування реакційної суміші, ампліфікація та інтерпретація результатів.

На етапі пробопідготовки проводять подрібнення, гомогенізацію зразка та приготування наважки.
Для екстракції (виділення) нуклеїнових кислот використовують велику кількість методів: метод фенольної екстракції, метод з використанням мікроколонок, метод, що базується на використанні магнітних частинок та автоматичне виділення.

Метод фенольної екстракиії порівняно не дорогий та не потребує додаткового обладнання. Недоліком $\epsilon$ низький вихід ДНК та ступінь чистоти. Цей метод потребує складних маніпуляцій, що можуть призвести до контамінації зразка (PCR Amplification; Andreeva, 2019).

Перевагою методу виділення нуклеїнових кислот на мікроколонках є чистота і якість отриманої ДНК, висока ефективність виділення і простота постановки, порівняно з попереднім методом. Екстракція на мікроколонках займає від 20 хв. залежно від досліджуваного матеріалу та має менший ризик контамінації. Недоліком вважають високу вартість (PCR Amplification; Andreeva, 2019).

Виділення з використанням магнітних частинокпросте у виконанні, характеризується високою частотою та якістю виділеної ДНК, не потребує використання додаткового лабораторного обладнання, його можна автоматизувати, займає менше часу при такій же кількості маніпуляцій, як попередній метод.

Метод автоматичного виділення, порівняно з попередніми методами, найшвидший та дає більший вихід нуклеїнових кислот високої якості з найменшим ризиком контамінації та виключенням людського фактору (PCR Amplification; Petrov et al., 2019).

Для очистки зразка від інгібіторів існує багато методів, вибір яких залежить від типу матриці та способу подальшої екстракції нуклеїнових кислот. При дослідженні жировмісних харчових продуктів користуються методом очистки з використанням гексану (Bessetti, 2007; Schrader et al., 2012).

Перевагою методу ПЛР є швидкість проведення, висока специфічність та чутливість (межа детектування становить $0,01 \%$, межа кількісного визначення $0,05 \%$ ). За допомогою даного методу можна досліджувати як м'ясну сировину, так і продукти, які пройшли технологічну обробку. Метод ПЛР дозволяє визначити кількісний вміст певного виду м'ясної сировини у готовому продукті та розроблений для перевірки технологічних процесів виготовлення м'ясних продуктів та напівфабрикатів без сторонніх домішок, і для визначення контамінації на виробничих лініях. Не підходить для визначення кількісного вмісту у готових м'ясних продуктах (сосиски, сардельки, варені ковбаси тощо), оскільки, вони містять додаткові компоненти, такі як: яєчний порошок, який дає у ПЛР позитивний сигнал на ДНК курей, сухе молоко - на ДНК ВРХ. Тому судити про правильність рецептурних закладок можна лише у випадку, коли для виробництва використовувались лише м'язові тканини тварин та спеції (PCR Amplification; Waiblinger et al., 2017). 


\section{Висновки}

Враховуючи відсоток фальсифікації м'ясних продуктів в Україні, виникла необхідність визначення їх видової приналежності. Велика кількість методів визначення фальсифікації (мікроструктурний, імунологічний) не дають змогу провести аналіз продуктів, які пройшли технологічну обробку, та визначити їх кількісний вміст. Найбільш оптимальним на сьогодні $\epsilon$ метод ПЛР - високоспецифічний, чутливий, який дозволяє встановити видову приналежність продукту та провести кількісний аналіз в термообробленій продукції.

Перспективами подальших досліджень є вдосконалення існуючих методів лабораторної діагностики та впровадження моніторингових досліджень видової приналежності з використанням методу ПЛР.

\section{References}

Andreeva, A. (2019). Top-5 sovremennyh metodik vydelenija nukleinovyh kislot. SkyGen, 2019 https://pcr.news/stati/top-5-sovremennykh-metodikvydeleniya-nukleinovykh-kislot/ (in Russian).

Bessetti, J. (2007). An introduction to PCR inhibitors. Profiles DNA, 10, 9-10. URL: https://www.promega.es//media/files/resources/profiles-in-dna/1001/anintroduction-to-pcr-inhibitors.pdf?la=es-es.

Fomina, T. A., \& Minaev, M. F. (2011). Sistema identifikacii dlja kontrolja haljal'noj mjasnoj produkcii. Mjasnaja industrija, 3, 32-34 (in Russian).

Humeniuk, H. D. (2009). Rehuliuvannia i zabezpechennia yakosti y bezpechnosti silskohospodarskoi ta khar-chovoi produktsii. Standartyzatsiia, yakist, sertyfikatsiia, 6, 6370. URL: http://nbuv.gov.ua/UJRN/ssia_2009_6_15 (in Ukrainian).

Informatsiina systema Yevropol [Elektronnyi resurs]. URL: https://pidru4niki.com/18210712/pravo/yevropol (in Ukrainian).

Ishchenko, L. M., Shynkarenko, L. M., Andrieiev, I. V., Kalakailo, L. I., Ishchenko, V. D., \& Spyrydonov, V. H. (2016). Identyfikatsiia DNK tvarynnoho pokhodzhennia $\mathrm{v}$ miasnykh produktakh ta kormakh dlia tvaryn metodom polimeraznoi lantsiuhovoi reaktsii $\mathrm{v}$ realnomu chasi. Science Rise, 11, 6-11. URL: http://nbuv.gov.ua/UJRN/texc_2016_11_3 (in Ukrainian).

Komarova, I. N. (2005). Razrabotka PCR-test-sistem dlja vidovoj identifikacii i kolichestvennoj ocenki mjasnogo syr'ja v sostave melkoizmel'chennyh polufabrikatov i gotovyh mjasnyh produktov: dis. kand. vet. nauk: spec. 16.00.06 "Veterinarnaja sanitarija, jekologija, zoogigiena i veterinarno-sanitarnaja jekspertiza". Moskva. URL: https://www.dissercat.com/content/razrabotkaptsr-test-sistem-dlya-vidovoi-identifikatsii-ikolichestvennoi-otsenki-myasnogo-s (in Russian).

Kotsiumbas, H. I., \& Shchebentovska, O. M. (2011). Ekspertyza varenykh kovbasnykh vyrobiv mikrostrukturnym metodom. URL: https://www.pdaa. edu.ua/sites/default/files/nppdaa-vet/2011/3/63.pdf (in Ukrainian).
Kotsiumbas, I. Ya., Kotsiumbas, H. I., \& Shchebentovska, O. M. (2011). Ekspertyza napivfabrykativ miasnykh ta miaso-roslynnykh sichenykh mikrostrukturnym metodom: metod. rek. Lviv: Afisha (in Ukrainian).

Krysanov, D. F. (2010). Yakist i bezpechnist kharchovoi produktsii. Ekonomika i prohnozuvannia, 3, 103-119. URL: http://nbuv.gov.ua/UJRN/econprog_2010_3_11 (in Ukrainian).

Khimich, M., Piven, O., Gorobey, O., Salata, V., Freiuk, D., \& Naidich, O. (2019). The analysis of the dynamics of detection animal's invasive diseases during veterinary expertise. Scientific Messenger of LNU of Veterinary Medicine and Biotechnologies. Series: Veterinary Sciences, 21(93), 149-154. doi: 10.32718/nvlvet9326.

Liubchyk, O., Mykyichuk, M., \& Honsor, O. (2014). Analiz shliakhiv udoskonalennia metodiv identyfikatsii vydiv miasa. Vymiriuvalna tekhnika ta metrolohiia: mizhvidomchyi naukovo-tekhnichnyi zbirnyk. Natsionalnyi universytet "Lvivska politekhnika" Lviv: Vydavnytstvo Natsionalnoho universytetu "Lvivska politekhnika", 75, 63-68 (in Ukrainian).

Lozhkina, O. V., Marchuk, O. T., Teplykh, N. I., Mezhenska, N. I., \& Kalynovska, I. H. (2013). Mikrostrukturnyi metod vyznachennia skladnykiv hotovoi produktsii iz miasnoi syrovyny. Veterynarni nauky, 155, 79-85 (in Ukrainian).

Nakaz Ministerstva okhorony zdorovia Ukrainy vid 24 sichnia 2008 roku N 26 "Pro zatverdzhennia derzhavnykh sanitarnykh norm i pravyl "Orhanizatsiia roboty laboratorii pry doslidzhenni materialu, shcho mistyt biolohichni patohenni ahenty I - IV hrup patohennosti molekuliarnohenetychnymy metodamy", [Elektronnyi resurs] https://zakon.rada.gov.ua/laws/show/z0088-08\#Text (in Ukrainian).

PCR Amplification. URL: https://worldwide.promega.com/ resources/guides/nucleic-acid-analysis/pcr-amplification.

P'ervinchenci, R. T. (2016). Farmakopejnaja Konvencija Soedinennyh Shtatov Ameriki. Vedomosti Nauchnogo centra jekspertizy sredstv medicinskogo primenenija, 2, 15-18. URL: https://www.vedomostincesmp.ru/jour/ article/view/73 (in Russian).

Petrov, D. G., Makarova, E. D., Germash, N. N., \& Antifeev, I. E. (2019). Metody vydelenija i ochistki DNK iz lizatov kletok (OBZOR). Nauchnoe priborostroenie, 29(4), 28-50. URL: https://cyberleninka.ru/article/n/ metody-vydeleniya-i-ochistki-dnk-iz-lizatov-kletokobzor (in Russian).

Schrader, C., Schielke, A., Ellerbroek, L., \& Johne, R. (2012). PCR inhibitors - occurrence, properties and removal. J Appl Microbiol, 113(5), 1014-1026. doi: 10.1111/j.1365-2672.2012.05384.x.

Shchebentovska, O. M., \& Kotsiumbas, H. I. (2012). Vazhlyvist metodiv mikroskopichnoho doslidzhennia pry vyiavlenni falsyfi-kativ miasnykh vyrobiv. Zbirnyk prats Natsionalnoho universytetu bioresursiv i pryrodokorystuvannia Ukrainy, 1, 508-509 (in Ukrainian). 
Shutchenko, P. O., Stehnii, B. T., \& Medvid, K. O. (2013). Mikrostrukturnyi analiz yak metod kontroliu skladu ta yakosti miasoproduktiv. Veterynarna medytsyna, 97, 491-492. URL: http://nbuv.gov.ua/UJRN/vetmed_2013_97_204 (in Ukrainian),

Sidnieva, Zh. K., \& Rybachuk-Yarova, T. V. (2015). Yakist kharchovoi produktsii - peredumova zabezpechennia prodovolchoi bezpeky krayiny. Stratehichni determinanty formuvannia stiikoho rozvytku APK Ukrai-ny: kol. monohr. Uman: Sochinskyi, 172-177. URL: http://dspace.nuft.edu.ua/ jspui/handle/123456789/20537 (in Ukrainian).

The EU Food Fraud Network. URL: https://ec.europa.eu/food/safety/food-fraud/ffn_en.

Vlizlo, V. V., Fedoruk, R. S., \& Ratych, I. B. (2012). Laboratorni metody doslidzhen u biolohii, tvarynnytstvi ta veterynarnii medytsyni: dovidnyk. Lviv: SPOLOM (in Ukrainian).
Waiblinger, H. U., Bartsch, D., Brockmeyer, J., BruenenNieweler, C., Busch, U., Haase, I., Hahn,, A., Haarmann, M., Hauser, W., Huber, I., Jany, K. D., Kirmse, N., Lindeke, S., Neumann, K., Naumann, H., Paschke, A., Pietsch, K., Pöpping, B., Reiting, R., Schroeder, U., Schwägele, F., Weller, M. G., \& Zagon, J. (2017). Methods of differentiating animal species in foods - Status quo Keywords "Animal species differentiation" "Fish species" PCR. Standardisation. Fleischwirtschaft international, 1.

Zakon Ukrainy (2018). "Pro informatsiiu dlia spozhyvachiv shchodo kharchovykh produktiv" Dokument 2639-VIII, chynnyi, potochna redaktsiia. Pryiniattia vid 06.12.2018, https://zakon.rada.gov.ua/laws/show/2639-19\#Text (in Ukrainian). 